\title{
An Input for Stakeholders' Management and Engagement Primer (SMEP) of Basic Education in the New Normal in Laguna Cluster, Philippines Insight
}

\author{
Melanie C. Caňo1, Consorcia S. Tan, EdD1, Marcial M. Bandoy, EdD1, Albert D. Yazon, EdD1, \\ Lerma P. Buenvinida, EdD ${ }^{1}$ \\ ${ }^{1}$ Teacher-III, Southville VI Elementary School, SDO Calamba City Professors, Laguna State Polytechnic \\ University, Los Baňos Campus, Philippines
}

\begin{abstract}
Crafting contingency plans and interventions in the Philippines' basic education in the new normal is the main concern of the study. Thus, stakeholders' support for basic education and the school's implementation in Laguna cluster for the school year 2020-2021 are also determined in this study. Descriptive correlational design was utilized in which 650 individuals served as respondents who are a combination of school heads, master teachers, and teachers in the city schools' division in Laguna. The result of the study revealed that there is a significant and positive correlation between stakeholder support and the degree of basic education delivery in the new normal, according to Pearson's Coefficient of Correlation. Stakeholder support for the implementation of basic education in the new normal was moderated by school size and demonstrated a high substantial relationship in terms of Learning Environment, Learning Support, Technology Support, Training and Development, and Direct Assistance. The use of regression coefficient showed that there is an immersive impact of school size on programs and tools in the delivery of basic education in the modern normal. On the other hand, there is no discernible interactive impact on the school scale. Hence, the empirical findings of the study were the basis of the researcher for the creation of a comprehensive contingency intervention plan. The Stakeholders' Management and Engagement Primer (SMEP) was crafted and recommended to all school leaders to bridge the gap between the stakeholders' support and the schools participating in the new normal adoption of basic education in Laguna cluster, Philippines.
\end{abstract}

Keywords: Stakeholders' Support, Basic Education, New Normal, Learning Delivery Modalities, Learning Continuity Plan

This is an open-access article under the CC-BY-NC license.

\section{INTRODUCTION}

With or without the coronavirus pandemic, every Filipino child deserves to finish school. Every Filipino is entitled to the advantages of education. The Philippines needs a well-educated population. According to Article XIV, section 1 of the Philippine Constitution of 1987, the state is responsible for protecting and promoting all citizens' right to quality education at all levels, as well as taking necessary measures to make such education available to all. As stated in section 2.1, the state must create, sustain, and support a comprehensive, adequate, and integrated educational system that meets the needs of the people and society. The right to education will be maintained.

However, the highly infectious coronavirus continues to pose unprecedented problems around the world. Students, teachers, school administrators, and donors are all getting used to it as a result. The most immediate consequence of coronavirus is the need to maintain strict social or physical distance to prevent or limit its dissemination, particularly in supporting the implementation of basic education in the new normal.

The existing phenomenon brought huge changes in all aspects of lives globally, specifically in the education sector. In the Philippines, the basic education shift from a normal setting, where face-to-face learning occur into new normal, where blended learning is mandated by virtue of Department of Education (DepEd) Order no. 12, series 2020 entitled, "Adoption of the Basic Education Learning Continuity Plan for the 
International Journal of Theory and Application in Elementary and Secondary School Education (IJTAESE), Vol. 3 (2), 76-90

An Input for Stakeholders' Management and Engagement Primer (SMEP) of Basic Education in the New Normal in Laguna Cluster, Philippines Insight

Melanie C. Caňo, Consorcia S. Tan, EdD, Marcial M. Bandoy, EdD, Albert D. Yazon, EdD, Lerma P. Buenvinida, EdD

school year 2020-2021 in the Light of COVID-19 Public Health Emergency”. The schools must find ways for learning to continue amidst the threat and uncertainties while ensuring the health, safety, and well-being of all learners, teachers, and personnel of the Department.

The new normal in basic education is critical without the support of the community and the nation vice-versa. Thus, the Republic Act (RA) 11494, also known as Bayanihan to Recover as One (BARO) Act of 2020 was implemented nationwide. Based on the RA 11494 page 25 section 7, the DepEd is fully supported by The national government when it comes to digital education, alternative learning modalities, and printing and delivery of self-learning modules. More so, section 272 of RA 7160, also known as the Local Government Code of 1991, mandated to provide a portion of the School Education Fund (SEF) in supporting the cited modalities and continuity plans relevant in mitigating COVID 19 pandemic and promoting a safe community.

RA 9155, also known as the Governance of Basic Education Act of 2001 empowered the school leaders, particularly the school heads, in managing public schools anchored on DepEd vision and mission. In this time of pandemic where the battle cry was learning must continue, school heads were armed with DO 12, s. 2020, RA11494, and RA 8525 Adopt-A-School Program (ASP), so that learning would be worthwhile and successful. Under RA 8525, private entities, both local and foreign, are allowed to become partners or stakeholders in education by assisting in the modernization and improvement of public elementary and secondary schools, especially in times of health crises or natural calamities.

Globally, there is evidence of various support of stakeholders in the public institution from the basic to the tertiary education sector. According to the United States of America (USA), as cited by Figlio and Kenny (2007), the contributions of stakeholders' support contributed to the public performance in the school grades, particularly in the state of Florida, USA. Sldo, Sdelmsn, and Taylor (2007) viewed school-community interaction as often "islands" with no bridges to the "mainland" that is why they underscored that every school and community interaction impacts student performance specifically in promoting well-being, resilience, protective factors, and empowering families. Thus, it is the main role of stakeholders in the school and community as mandated by the law of the land.

In connection, the researcher aims to ensure that the quality of teaching and learning is not neglected amidst the global pandemic through the support of stakeholders and how continual learning happens despite health and other challenges. Thus, determined the relationship between the level of stakeholders' support and the level of the implementation of basic education in the new normal in Laguna cluster. Hence, its findings are expected to help improve the quality of services in the safest ways in which public health and wellness is the highest priority.

Specifically, the study sought answers to the following questions:

1. What is the level of stakeholders' support in the implementation of basic education in The new normal in the elementary schools in city divisions in Laguna cluster SY 2020-2021?

2. What is the level of implementation of basic education in the new normal as supported by stakeholders in the elementary schools in city divisions in Laguna cluster SY 2020-2021?

3. Is there a significant relationship between the level of stakeholders' support and the level of implementation of basic education in the new normal in the elementary city divisions in Laguna cluster SY 2020-2021?

4. Does the level of stakeholders' s support predict the level of implementation of basic education in the new normal in the elementary city divisions in Laguna cluster SY 2020-2021?

5. Does the school size moderate the relationship between the level of stakeholders' support and the level of implementation of basic education in the new normal in the elementary city divisions in Laguna cluster SY 2020-2021?

6. Based on the result of the study, what stakeholders' management and engagement plan can be proposed to elementary schools and the stakeholders in support of the implementation of basic education in the new normal in the elementary city divisions in Laguna Cluster SY 2020-2021?

\section{LITERATURE REVIEW}


International Journal of Theory and Application in Elementary and Secondary School Education (IJTAESE), Vol. 3 (2), 76-90

An Input for Stakeholders' Management and Engagement Primer (SMEP) of Basic Education in the New Normal in Laguna Cluster, Philippines Insight

Melanie C. Caňo, Consorcia S. Tan, EdD, Marcial M. Bandoy, EdD, Albert D. Yazon, EdD, Lerma P. Buenvinida, EdD

The Theory of Change (TOC) is the foundation of the research paper. According to Laan (2019), TOC is a systematic explanation and example of how and why a change is supposed to occur in each situation. This shift focuses on figuring out or "filling in" what has been referred to as the "missing center" between what a program or change effort does (its actions or interventions) and how these contribute to the achievement of desired goals. In this regard, the introduction of basic education has shifted from the old to the modern normal, which is critical in the research.

The implementation of basic education in the new normal was changed or "filling in" and "missing middle" as stated in the TOC. Learners and Teachers, even parents, were overwhelmed by how the school operates amidst COVID19. But through the virtue of DepEd Order no. 12, series 2020 or the implementation of BE-LCP, learning will continue, and the desired goals of DepEd are to be achieved through the "missing middle"- stakeholders' support. The missing middle could be strengthening the stakeholders' support through the implementation of ASP and interventions through the Stakeholders' Management and Engagement Primer (SMEP).

Kurt Lewin's Force Field Theory is another important theory. There are forces pushing change (government interference, societal values, technological changes, knowledge explosion, and administrative support) and forces restricting it (government intervention, societal values, technological changes, knowledge explosion, and administrative support) in Lewin's model. Forces at work (fear of the unknown, negative attitudes to change, traditional values, limited resources, and obsolete equipment). There will be no change where the two sets of forces are in equilibrium.

The sudden shift from the traditional face-to-face physical classroom environment to an online virtual environment during the COVID-19 pandemic has affected the ability to cope among the students and teachers. Unifying strategies across stakeholders in supporting such a transition can lessen the mental burden and promote a resilient educational community towards developing competent students and teachers. Moreover, the importance of the support of stakeholders, particularly internal parents/teachers, magnified in the study of Bartolome et al. (2017). It was reflected that the support of the immediate stakeholders would benefit the child in his learning achievement. Each child can either be molded to be successful or made to fail in life. Thus, the support of stakeholders was vital in the child's continual learning progress. Hence, the urgency of the implementation of basic education in the new normal implicates the level of support from stakeholders.

Thus, reviews and empirical findings on stakeholders' support in the implementation of basic education in the new normal in Laguna and the other countries was only limited. Hence, the researcher pushed to investigate to contribute to the immerging issues and challenges in public schools brought by global pandemic to bridge between the gaps on school needs and stakeholders' support and provide interventions to mitigate the challenges arisen.

\section{RESEARCH METHOD}

The study employed the descriptive correlational research design. The survey method was applied to 650 internal stakeholders-respondents in elementary schools' city division in the Laguna cluster for the school year 2020-2021. Laguna cluster is comprising of divisions cities of Biñan, Cabuyao, Calamba, San Pablo, and Sta. Rosa. According to Adanza (2009), it is designed to gather information about present conditions, status, or trends and deal with what is prevailing. Proportional

Random Sampling Technique was employed in the study. The 6,178 total population was divided into subpopulations, and then applied a random sampling technique to each subpopulation to get the 650 respondents.

The research instrument was adopted and modified based on the respondents' locale and has undergone a validation process from the experts. The assessment for the validity of the instrument revealed "very high valid" with 4.78 composite mean results and 1.20 SD. Cronbach's Alpha Reliability Test result showed that the tool has 36 components, has a 15.22 sum of the item variances, 163.95 variances of the total score, and $93.31 \%$ reliability.

The researcher secured permission to survey the Division Superintendents of five (5) city divisions in Laguna Cluster. The date and time of accomplishing the online survey questionnaire were agreed upon by the 
International Journal of Theory and Application in Elementary and Secondary School Education (IJTAESE), Vol. 3 (2), 76-90 An Input for Stakeholders' Management and Engagement Primer (SMEP) of Basic Education in the New Normal in Laguna Cluster, Philippines Insight

Melanie C. Caňo, Consorcia S. Tan, EdD, Marcial M. Bandoy, EdD, Albert D. Yazon, EdD, Lerma P. Buenvinida, EdD

researcher dated February 15 to May 7, 2021, city division focal persons, and the respondents. The information reflected from the answered questionnaire was automatically recorded through google forms. It was analyzed and interpreted using an appropriate statistical test such as the mean and standard deviation, Pearson's Coefficient of Correlation, Multiple Linear Regression.

\section{FINDINGS AND DISCUSSION}

Table 1 shows the level of stakeholders' support in the implementation of basic education in terms of the provision for the learning environment as revealed "supported" with a composite mean of 2.72 and 0.98 SD.

Table 1. Level of Stakeholders' Support in the Implementation of Basic Education in terms of the Provision for the Learning Environment

\begin{tabular}{|l|c|c|c|}
\hline \multicolumn{1}{|c|}{ Learning Environment } & Mean & SD & Verbal Description \\
\hline Construction of a newclassroom & 2.66 & 1.12 & Supported \\
\hline $\begin{array}{l}\text { Rehabilitation or repair fflearning } \\
\text { facilities }\end{array}$ & 2.80 & .914 & Supported \\
\hline Construction of toilet \& wash facilities & 2.87 & .916 & Supported \\
\hline $\begin{array}{l}\text { Renovation/Repair of sanitary } \\
\text { facilities }\end{array}$ & 2.86 & .906 & Supported \\
\hline $\begin{array}{l}\text { Donation of real property to expand } \\
\text { learning facilities }\end{array}$ & 2.44 & 1.02 & $\begin{array}{c}\text { Moderately } \\
\text { Supported }\end{array}$ \\
\hline \multicolumn{1}{|c|}{ Overall } & 2.72 & 0.98 & Supported \\
\hline
\end{tabular}

Legend: (4.51 - 5.00) Extremely Supported (ES); (3.51 - 4.50) Highly Supported (HS); 2.51 - 3.50 Supported (S); (1.51 - 2.50) Moderately Supported (MS); (1.00 - 1.50) Not Supported (NS)

The donations of real property to expand learning facilities were "moderately supported" by the stakeholders with 2.44 mean and 1.02 SD. It simply affirmed that schools are in communities but often islands with no bridges to the mainland (Adelman and Taylor, 2006).

Shown in table 2 is the level of stakeholders' support in the implementation of basic education in the new normal in terms of provision for the assistive learning devices with a 2.72 composite mean and $1.10 \mathrm{SD}$, which means "supported".

Table 2. Level of Stakeholders Support in the Implementation of Basic Education in terms of the Provision for the Assistive Learning Devices

\begin{tabular}{|c|c|c|c|}
\hline $\begin{array}{c}\text { Learning Support/Assistive Learning } \\
\text { Devices }\end{array}$ & Mean & $\mathrm{SD}$ & Verbal Description \\
\hline $\begin{array}{l}\text { Provision of audio-visual educational } \\
\text { materials }\end{array}$ & 2.73 & .94 & Supported \\
\hline Provision of schoolsupplies & 3.37 & .77 & Supported \\
\hline Donation of Educational film/library & 2.76 & .88 & Supported \\
\hline $\begin{array}{l}\text { Donation of PencilGrip, Special } \\
\text { Chair }\end{array}$ & 2.47 & .98 & $\begin{array}{l}\text { Moderately } \\
\text { Supported }\end{array}$ \\
\hline $\begin{array}{l}\text { Donation of Spelling Check Devices, } \\
\text { Hearing aides }\end{array}$ & 2.28 & .98 & $\begin{array}{l}\text { Moderately } \\
\text { Supported }\end{array}$ \\
\hline Overall & 2.72 & 1.10 & Supported \\
\hline
\end{tabular}


International Journal of Theory and Application in Elementary and Secondary School Education (IJTAESE), Vol. 3 (2), 76-90 An Input for Stakeholders' Management and Engagement Primer (SMEP) of Basic Education in the New Normal in Laguna Cluster, Philippines Insight

Melanie C. Caňo, Consorcia S. Tan, EdD, Marcial M. Bandoy, EdD, Albert D. Yazon, EdD, Lerma P. Buenvinida, EdD

Legend: (4.51 - 5.00) Extremely Supported (ES); (3.51 - 4.50) Highly Supported (HS); 2.51 - 3.50 Supported (S); (1.51 - 2.50) Moderately Supported (MS); $(1.00$ - 1.50) Not Supported (NS)

Donating assistive learning devices such as educational film or library, pencil grip, special chair, spelling check devices, and hearing aids was "moderately supported" with 2.28 to 2.786 means. Walner in 2008 compared Alberta and Ontario in Canada, having common agenda of education reform, including learning support in education through stakeholders' support. But Alberta achieved success while Ontario experienced a series of setbacks and lost the support of education, stakeholders, and the public. It somehow supports the result on the afore-cited data that learning support can be compromised even in the first world country, but more on to the third world like the Philippines.

Presented in table 3 is the level of stakeholders' support in the implementation of basic education in terms of technical support as "supported" with 2.67 composites mean and 0.95 SD. It indicates that smartphones or electronic gadgets for learning and sports materials were "moderately supported," as reflected in the 2.46 mean and $.98 \mathrm{SD}$. Technology support to learners and teachers is very relevant in this time of the pandemic, specifically in terms of communication. In relation, Samsung Electronics in Calamba was one of the supportive stakeholders of public elementary schools in terms of donation of multimedia materials from the year 2013 to the present. Thus, ABS-CBN Lingkod Kapamilya also donated multi-media materials in some of the public elementary schools in Calamba, including Southville VI Elementary school, by the year 2013.

Table 3. Level of Stakeholders Support in the Implementation of Basic Education in terms of the Technology Support

\begin{tabular}{|l|c|c|c|}
\hline Learning Support/Assistive Learning Devices & Mean & SD & Verbal Description \\
\hline $\begin{array}{l}\text { Donation of computers or laptops for } \\
\text { teaching and learning purposes }\end{array}$ & 2.73 & .96 & Supported \\
\hline $\begin{array}{l}\text { Provision for electronic learning } \\
\text { materials }\end{array}$ & 2.75 & .93 & Supported \\
\hline Provision of secure internet connectivity & 2.99 & .93 & Supported \\
\hline Donation of Multimedia materials & 2.63 & .96 & Supported \\
\hline $\begin{array}{l}\text { Donation of smartphones or electronic } \\
\text { gadgets for learning }\end{array}$ & 2.46 & .98 & Moderately Supported \\
\hline $\begin{array}{l}\text { Donation of sports materials and } \\
\text { equipment }\end{array}$ & 2.48 & .95 & Moderately Supported \\
\hline \multicolumn{1}{|c|}{ Overall } & 2.67 & 0.95 & Supported \\
\hline
\end{tabular}

Legend: (4.51 - 5.00) Extremely Supported (ES); (3.51 - 4.50) Highly Supported (HS); 2.51 - 3.50 Supported (S); (1.51 - 2.50) Moderately Supported (MS); $(1.00-1.50)$ Not Supported (NS)

Table 4 illustrates the level of stakeholders' support in the implementation of basic education in terms of provision for health and nutrition, which is revealed as "supported" with a 3.28 composite mean and 0.83 SD. It conveys that feeding programs and health supplies were "highly supported," as seen in the result of the mean ranging from 3.52 to 3.63 .

It affirms that DepEd flagship's program "Sulong Edukalidad" in the new normal setting where health and safety of teachers and learners tend to compromise due to global health outbreak was at least mitigated as indicated by the findings. 
International Journal of Theory and Application in Elementary and Secondary School Education (IJTAESE), Vol. 3 (2), 76-90 An Input for Stakeholders' Management and Engagement Primer (SMEP) of Basic Education in the New Normal in Laguna Cluster, Philippines Insight

Melanie C. Caňo, Consorcia S. Tan, EdD, Marcial M. Bandoy, EdD, Albert D. Yazon, EdD, Lerma P. Buenvinida, EdD

Table 4. Level of Stakeholders Support in the Implementation of Basic Education in terms of the Provision for the Health and Nutrition

\begin{tabular}{|c|c|c|c|}
\hline Health and Nutrition & Mean & SD & Verbal Description \\
\hline Feeding program & 3.63 & .67 & Highly Supported \\
\hline Medical/Dental & 3.08 & .90 & Supported \\
\hline Mission/check-ups & 3.18 & 86 & Supported \\
\hline Deworming & 3.51 & .77 & Highly Supported \\
\hline Intervention & 3.00 & .93 & Supported \\
\hline Overall & 3.28 & 0.95 & Supported \\
\hline
\end{tabular}

Legend: (4.51 - 5.00) Extremely Supported (ES); (3.51 - 4.50) Highly Supported (HS); 2.51 - 3.50 Supported (S); (1.51 - 2.50) Moderately Supported (MS); $(1.00-1.50)$ Not Supported (NS)

Table 5 reveals that Reading Programs were "supported" by the stakeholders as seen in the 3.14 composite mean and $0.89 \mathrm{SD}$.

Table 5. Level of Stakeholders Support in the Implementation of Basic Education in terms of the Provisions for the Reading Program

\begin{tabular}{|l|c|c|c|}
\hline \multicolumn{1}{|c|}{ Reading Program } & Mean & SD & Verbal Description \\
\hline $\begin{array}{l}\text { Donation of ECARP (Every Child a } \\
\text { Reading Program) materials and tools }\end{array}$ & 3.24 & .88 & Supported \\
\hline $\begin{array}{l}\text { Supported Project BELL- ELLN (Early } \\
\text { Language Literacy and Numeracy) }\end{array}$ & 3.29 & .84 & Supported \\
\hline $\begin{array}{l}\text { Provision of supplementary reading } \\
\text { materials }\end{array}$ & 3.19 & .86 & Supported \\
\hline $\begin{array}{l}\text { Donation of supplies for research on } \\
\text { reading enhancement }\end{array}$ & 2.83 & .92 & Supported \\
\hline Supported pupil-achiever in reading & 3.16 & .94 & Supported \\
\hline \multicolumn{1}{|c|}{ Overall } & 3.14 & 0.89 & Supported \\
\hline
\end{tabular}

Legend: (4.51 - 5.00) Extremely Supported (ES); (3.51 - 4.50) Highly Supported (HS); 2.51 - 3.50 Supported (S); $(1.51-2.50)$ Moderately Supported (MS); $(1.00-1.50)$ Not Supported (NS)

The donation of supplies for research on reading enhancement, Project BELL, and ELLN, ECARP materials and tools, and pupil-achiever in reading revealed as "supported" with a mean ranging from 2.83 to 3.29. Stakeholder's support in the implementation of basic education in the new normal for reading program is reflected on Dakar Framework of Action and Philippine EFA 2015 during the World Educational Forum (2008).

The main goal is to give everyone basic skills and to achieve functional literacy. Assuring that every Filipino possesses the fundamental skillsets is the same as ensuring that all Filipinos are functionally literate. Table 6 reveals the level of stakeholders' support in the implementation of basic education in terms of training and development as "supported" with a 3.10 composite mean and 0.92 SD.

Table 6. Level of Stakeholders Support in the Implementation of Basic Education in terms of the Provision for Training and Development

\begin{tabular}{|c|c|c|c|}
\hline Training and Development & Mean & SD & Verbal Description \\
\hline Teachers/Principal Training & 3.47 & .78 & Supported \\
\hline
\end{tabular}


International Journal of Theory and Application in Elementary and Secondary School Education (IJTAESE), Vol. 3 (2), 76-90 An Input for Stakeholders' Management and Engagement Primer (SMEP) of Basic Education in the New Normal in Laguna Cluster, Philippines Insight

Melanie C. Caňo, Consorcia S. Tan, EdD, Marcial M. Bandoy, EdD, Albert D. Yazon, EdD, Lerma P. Buenvinida, EdD

\begin{tabular}{|l|c|c|c|}
\hline Students/Pupils Training & 3.18 & .86 & Supported \\
\hline $\begin{array}{l}\text { 21st Century Teaching \& Learning } \\
\text { Enhancement }\end{array}$ & 2.27 & .85 & Moderately Supported \\
\hline Educational Tour & 2.27 & 1.06 & Moderately Supported \\
\hline National/International Sponsorship & 2.42 & 1.00 & Moderately Supported \\
\hline Sports Training & 2.56 & .99 & Supported \\
\hline \multicolumn{1}{|c|}{ Overall } & 3.14 & 0.89 & Supported \\
\hline
\end{tabular}

Legend: (4.51 - 5.00) Extremely Supported (ES); (3.51 - 4.50) Highly Supported (HS); 2.51 - 3.50 Supported (S); (1.51 - 2.50) Moderately Supported (MS); $(1.00-1.50)$ Not Supported (NS)

As shown in table 6, educational tours and 21st- century teaching and learning enhancement were "moderately supported," as shown in the same mean result of 2.27. It simply means that visitation to different educational places was restricted since the purpose of DepEd Order no. 12, series 2020, was for basic education continuity during the COVID-19 pandemic following standard health protocols set by IATF.

Table 7 illustrates the level of stakeholders' support in the Implementation of basic education in terms of stakeholders' direct assistance with 2.98 composites mean and 1.01 SD, which means "supported".

It revealed that stakeholders "supported" with a mean of 2.88 to 3.03 direct assistance in 5 city school divisions in the Laguna cluster. This means that the direct donations of cash, stipends, learning materials, office materials, and sponsorship were directly extended by stakeholders even in the most vulnerable health status of schools and communities.

Table 7. Level of Stakeholders Support in the Implementation of Basic Education in terms of Direct Assistance

\begin{tabular}{|l|c|c|c|}
\hline \multicolumn{1}{|c|}{ Direct Assistance } & Mean & SD & Verbal Description \\
\hline $\begin{array}{l}\text { Donation of cash or stipends directly } \\
\text { from donors }\end{array}$ & 3.00 & 1.02 & Supported \\
\hline $\begin{array}{l}\text { Donation of learning materials without } \\
\text { any appointment from the donors }\end{array}$ & 3.03 & .950 & Supported \\
\hline $\begin{array}{l}\text { Provision of office materials without } \\
\text { any appointment from the donors }\end{array}$ & 3.00 & .988 & Supported \\
\hline $\begin{array}{l}\text { Direct sponsorship/scholarship for } \\
\text { pupils }\end{array}$ & 2.88 & 1.07 & Supported \\
\hline \multicolumn{1}{|c|}{ Overall } & 2.88 & 1.01 & Supported \\
\hline
\end{tabular}

Legend: (4.51 - 5.00) Extremely Supported (ES); (3.51 - 4.50) Highly Supported (HS); 2.51 - 3.50 Supported (S); $(1.51-2.50)$ Moderately Supported (MS); $(1.00-1.50)$ Not Supported (NS)

In table 8, it was evident that the level of implementation of basic education in the new normal as supported by stakeholders in terms of all Learning Delivery Modalities (LDMs) revealed as "implemented" with a mean result of 2.74 to 3.50 and 3.05 composite mean, $0.90 \mathrm{SD}$.

Table 8. Level of Implementation of Basic Education in the New Normal as Supported by the Stakeholders in terms of the Learning Delivery Modalities

\begin{tabular}{|l|c|c|c|}
\hline \multicolumn{1}{|c|}{ Learning Delivery Modalities } & Mean & SD & Verbal Description \\
\hline $\begin{array}{l}\text { Blended Learning (combines face-to- } \\
\text { face with any or a mix of ODL, MDL, } \\
\text { TV-based/Radio-based instruction }\end{array}$ & 3.02 & .991 & Implemented \\
\hline $\begin{array}{l}\text { Modular Distance Learning-Printed } \\
\text { (using SLM's, books, any LM's available) }\end{array}$ & 3.35 & .760 & Implemented \\
\hline Modular Distance Learning- Non & 3.31 & .880 & Implemented \\
\hline
\end{tabular}

82 
International Journal of Theory and Application in Elementary and Secondary School Education (IJTAESE), Vol. 3 (2), 76-90 An Input for Stakeholders' Management and Engagement Primer (SMEP) of Basic Education in the New Normal in Laguna Cluster, Philippines Insight

Melanie C. Caňo, Consorcia S. Tan, EdD, Marcial M. Bandoy, EdD, Albert D. Yazon, EdD, Lerma P. Buenvinida, EdD

\begin{tabular}{|l|c|c|c|}
\hline $\begin{array}{l}\text { printed (using PC, tablet, smartphones, } \\
\begin{array}{l}\text { USB storage, CD's, DVD's, any available } \\
\text { gadgets) }\end{array}\end{array}$ & & \\
\hline $\begin{array}{l}\text { TV-Based Instruction (utilizes SLMs } \\
\text { converted to video) }\end{array}$ & 2.85 & .905 & Implemented \\
\hline Radio-Based Instruction & 2.74 & .968 & Implemented \\
\hline \multicolumn{1}{|c|}{ Overall } & 3.05 & 0.90 & Implemented \\
\hline
\end{tabular}

Legend: (4.51 - 5.00) Extremely Implemented/Supported (EI, ES); (3.51 - 4.50) Highly Implemented/Supported (HI, HS); 2.51 - 3.50 Implemented/Supported (I, S); (1.51 - 2.50) Moderately Implemented/Supported (MI, MS); (1.00 - 1.50) Not Implemented/Supported (NI,NS)

The level of implementation of basic education in the new normal as supported by stakeholders in terms of Most essential Learning (MELCs) is reflected in table 9 with 3.24 composite and 0.83 SD. It suggests that the orientation on the contents of MELCs before the start of the school year was "highly implemented," thus highly supported by the stakeholders with 3.55 mean and .714 SD.

Table 9. Level of Implementation of Basic Education in the New Normal as Supported by the Stakeholders in terms of Most Essential Learning Competencies

\begin{tabular}{|l|c|c|c|}
\hline \multicolumn{1}{|c|}{ Most Essential Learning Competencies } & Mean & SD & Verbal Description \\
\hline $\begin{array}{l}\text { Orientation on the contents of MELCs } \\
\text { before the start of SY }\end{array}$ & 3.55 & .714 & Highly Implemented \\
\hline $\begin{array}{l}\text { Identification and usage of MELCS in } \\
\text { WHLP }\end{array}$ & 3.36 & .790 & Implemented \\
\hline $\begin{array}{l}\text { Harmonization of MELCs contents to } \\
\text { higher concepts across content areas }\end{array}$ & 3.22 & .832 & Implemented \\
\hline $\begin{array}{l}\text { Application of MELCs to real-life } \\
\text { situations) }\end{array}$ & 3.14 & .860 & Implemented \\
\hline Reproduction and printing of MELCs & 2.92 & .942 & Implemented \\
\hline \multicolumn{1}{|c|}{ Overall } & 3.24 & 0.83 & Implemented \\
\hline
\end{tabular}

Legend: (4.51 - 5.00) Extremely Implemented/Supported (EI, ES); (3.51 - 4.50) Highly Implemented/Supported (HI, HS); 2.51 - 3.50 Implemented/Supported (I, S); (1.51 - 2.50) Moderately Implemented/Supported (MI, MS); (1.00 - 1.50) Not Implemented/Supported (NI,NS)

Moreover, identification and usage of MELCS in WHLP, harmonization of MELCs contents to higher concepts across content areas, application of MELCs to real-life situations, and reproduction and printing of MELCs revealed "implemented" with mean ranging from 2.92 to 3.36 mean result as cited in table 9. It was evident that teachers nationwide encountered challenges in identifying, harmonizing, and applying MELCS in the implementation of basic education in the new normal. It was apparent in the study of Tupas and Laguda (2020), who concluded that this pandemic had placed educational institutions in a difficult position, especially because the government has proclaimed and decreed that no face-to-face classes will be held in the school year 2020-2021.

Table 10 presents the level of implementation of basic education in the new normal as supported by stakeholders in terms of PIVOT 4A- CALABARZON Budget of Work (BOW) with a 3.20 composite mean and 0.85 SD. The 3.55 mean and .716 SD results describe as "highly implemented" in terms of stakeholders' support in the orientation on the contents of BOW before the start of the school year.

This is confirmed by Toguero (2020), who stated that there is a greater need for educational institutions to strengthen curriculum practices and make them more sensitive to students' learning needs outside of traditional classrooms.

Identification and usage of BOW in WHLP with mean of 3.31 and .802 SD, Harmonization of BOW contents to higher concepts across content areas (mean=3.18 and SD=.864), Application of BOW to real-life situations (Mean=3.08 and SD= .897), and Reproduction and printing of BOW (Mean=2.88 and SD=.946) 
International Journal of Theory and Application in Elementary and Secondary School Education (IJTAESE), Vol. 3 (2), 76-90 An Input for Stakeholders' Management and Engagement Primer (SMEP) of Basic Education in the New Normal in Laguna Cluster, Philippines Insight

Melanie C. Caňo, Consorcia S. Tan, EdD, Marcial M. Bandoy, EdD, Albert D. Yazon, EdD, Lerma P. Buenvinida, EdD

revealed that stakeholders "implemented" the implementation of basic education in the new normal in terms of the afore-cited BOW indicators.

It simply means that leaping past the challenges brought by the COVID-19 pandemic will require a united response from stakeholders, or often said, "It takes a village to educate a child as reflected in DO 32, series of 2020 .

Table 10. Level of Implementation of Basic Education in the New Normal as Supported by Stakeholders in terms of the PIVOT 4A-CALABARZON Budget of Work (BOW)

\begin{tabular}{|c|c|c|c|}
\hline $\begin{array}{l}\text { PIVOT 4A- CALABARZON Budget of Work } \\
\text { (BOW) }\end{array}$ & Mean & SD & Verbal Description \\
\hline $\begin{array}{l}\text { Orientation on the contents of BOW } \\
\text { before the start of SY }\end{array}$ & 3.55 & .716 & Highly Implemented \\
\hline $\begin{array}{l}\text { Identification and usage of BOW in } \\
\text { WHLP }\end{array}$ & 3.31 & .802 & Implemented \\
\hline $\begin{array}{l}\text { Harmonization of BOW contents to } \\
\text { higher concepts across content areas }\end{array}$ & 3.18 & .864 & Implemented \\
\hline $\begin{array}{l}\text { Application of BOW to real-life } \\
\text { situations }\end{array}$ & 3.08 & .897 & Implemented \\
\hline Reproduction and printing of BOW & 2.88 & .946 & Implemented \\
\hline Overall & 3.20 & 0.85 & Implemented \\
\hline
\end{tabular}

Legend: (4.51 - 5.00) Extremely Implemented/Supported (EI, ES); (3.51 - 4.50) Highly Implemented/Supported (HI, HS); 2.51 - 3.50 Implemented/Supported (I, S); (1.51 - 2.50) Moderately Implemented/Supported (MI, MS); (1.00 -1.50) Not Implemented/Supported (NI,NS)

Table 11 illustrates the level of implementation of basic education in the new normal as supported by stakeholders in terms of Weekly Home Learning Plan (WHLP) having a 3.16 composite mean and 0.86 SD. It revealed that orientation on the contents of WHLP before the start of the school year was "highly with 3.54 mean and .725 SD. on the contents of WHLP before the start of the school year conducted by DepEd obtained high support from the stakeholders.

On the other hand, the construction and usage of WHLP in teaching, retrieval, and distribution of WHLP to parents or guardians and reproduction and printing of WHLP were "implemented" with a mean ranging from 2.89 to 3.09 .

Table 11. Level of Implementation of Basic Education in New Normal as Supported by Stakeholders in terms of the Weekly Home Learning Plan

\begin{tabular}{|l|c|c|c|}
\hline \multicolumn{1}{|c|}{ Weekly Home Learning Plan } & Mean & SD & Verbal Description \\
\hline Orientation on the contents of WHLP & 3.54 & .752 & Highly Implemented \\
\hline $\begin{array}{l}\text { Construction and usage of WHLP in } \\
\text { teaching }\end{array}$ & 3.31 & .821 & Implemented \\
\hline Reproduction and printing of WHLP & 2.89 & .945 & Implemented \\
\hline $\begin{array}{l}\text { Distribution of WHLP and pupil's } \\
\text { outputs to parents/guardians }\end{array}$ & 2.98 & .920 & Implemented \\
\hline $\begin{array}{l}\text { Retrieval of WHLP and pupil's outputs } \\
\text { to parents/guardians }\end{array}$ & 3.09 & .887 & Implemented \\
\hline \multicolumn{1}{|c|}{ Overall } & 3.16 & 0.86 & Implemented \\
\hline
\end{tabular}


International Journal of Theory and Application in Elementary and Secondary School Education (IJTAESE), Vol. 3 (2), 76-90 An Input for Stakeholders' Management and Engagement Primer (SMEP) of Basic Education in the New Normal in Laguna Cluster, Philippines Insight

Melanie C. Caňo, Consorcia S. Tan, EdD, Marcial M. Bandoy, EdD, Albert D. Yazon, EdD, Lerma P. Buenvinida, EdD

Legend: (4.51 - 5.00) Extremely Implemented/Supported (EI, ES); (3.51 - 4.50) Highly Implemented/Supported (HI, HS); 2.51 - 3.50 Implemented/Supported (I, S); (1.51 - 2.50) Moderately Implemented/Supported (MI, MS); (1.00 - 1.50) Not Implemented/Supported (NI,NS)

Table 12 reveals the level of implementation of basic education in the new normal as supported by stakeholders in terms of Learning Continuity Plan (LCP) was "implemented" with 2.90 composites mean and 0.89 SD. The implementation of learning delivery modalities (LDMs) safely was "highly implemented" by the schools as supported by stakeholders.

In connection, Kuswardhani (2020) explained the leadership practices within the context of Distributed Leadership (DL) amidst the global pandemic. He also said that stakeholder collaboration is significant in DL. DO Number 12 series 2020 mandates that LCP shall be initiated by the school heads and as stipulated in RA 9155. It simply means that stakeholders have high support with school heads among the city schools' divisions, particularly in leading the implementation of LDMs safely and vice versa.

Among the LCP indicators, the least "implemented" was the provision of devices that a learner can use for learning with 2.69 mean and .957 SD. Tarek (2016) underscored that distance learning necessitates a high level of engagement between the teacher and students; the teacher must address any learning issues that students may face while taking into account the students' particular needs in terms of learning styles.

Table 12. Level of Implementation of Basic Education in the New Normal as Supported by Stakeholders in terms of the Learning Continuity Plan

\begin{tabular}{|l|c|c|c|}
\hline \multicolumn{1}{|c|}{ Weekly Home Learning Plan } & Mean & SD & Verbal Description \\
\hline Implemented learning modalities safely & 3.54 & .704 & Highly Implemented \\
\hline Provided available gadgets/ equipment & 2.88 & .919 & Implemented \\
\hline $\begin{array}{l}\text { Provision of load assistance/ data } \\
\text { allowance }\end{array}$ & 2.73 & .976 & Implemented \\
\hline $\begin{array}{l}\text { Mitigated unstable mobile/ internet } \\
\text { connection }\end{array}$ & 2.85 & .920 & Implemented \\
\hline $\begin{array}{l}\text { Reduction of existing health } \\
\text { condition/s }\end{array}$ & 2.84 & .892 & Implemented \\
\hline $\begin{array}{l}\text { Reduced difficulty in independent } \\
\text { learning }\end{array}$ & 2.84 & .889 & Implemented \\
\hline $\begin{array}{l}\text { Managed and guided conflicts with } \\
\text { other activities (i.e., house chores) }\end{array}$ & 2.85 & .884 & Implemented \\
\hline $\begin{array}{l}\text { Provided available studying area } \\
\text { within the community if lack at home }\end{array}$ & 2.69 & .939 & Implemented \\
\hline $\begin{array}{l}\text { Managed distractions (i.e., social media, } \\
\text { noise from community/neighbor) }\end{array}$ & 2.79 & .911 & Implemented \\
\hline $\begin{array}{l}\text { Provided devices at home that a learner } \\
\text { can use for learning }\end{array}$ & 2.69 & .957 & Implemented \\
\hline $\begin{array}{l}\text { Assisted the household members who } \\
\text { could not provide instructional support } \\
\text { to the child's distance learning }\end{array}$ & 2.94 & .870 & Implemented \\
\hline $\begin{array}{l}\text { Conducted safe and relative training for } \\
\text { teachers and parents }\end{array}$ & 3.21 & .868 & Implemented \\
\hline \multicolumn{1}{c}{ Overall } & 2.90 & 0.89 & Implemented \\
\hline
\end{tabular}

Legend: (4.51 - 5.00) Extremely Implemented/Supported (EI, ES); (3.51 - 4.50) Highly Implemented/Supported (HI, HS); 2.51 - 3.50 Implemented/Supported (I, S); (1.51 - 2.50) Moderately Implemented/Supported (MI, MS); (1.00 -1.50) Not Implemented/Supported (NI,NS) 
International Journal of Theory and Application in Elementary and Secondary School Education (IJTAESE), Vol. 3 (2), 76-90

An Input for Stakeholders' Management and Engagement Primer (SMEP) of Basic Education in the New Normal in Laguna Cluster, Philippines Insight

Melanie C. Caňo, Consorcia S. Tan, EdD, Marcial M. Bandoy, EdD, Albert D. Yazon, EdD, Lerma P. Buenvinida, EdD

Table 13 presents the level of implementation of basic education in the new normal as supported by stakeholders in terms of Learning Delivery Modality for teachers (LDM2), which revealed as "implemented" with a 3.37 composite mean and $0.71 \mathrm{SD}$.

The findings suggest that all indicators cited by LDM2 were "highly implemented" by the schools and were highly supported by stakeholders from module 1 to module 4, as shown in the mean result ranging from 3.57 to 3.58. LDM2 for teachers includes Professional Development and LAC Planning for the module, Course Orientation of teachers for module 1, and Most Essential Learning Competencies (MELCs), and module 3 for Learning Resources. Module 3a- Lesson Design and Assessment had the least mean of 2.57 although revealed as "implemented" and only supported by the stakeholders.

Table 13. Level of Implementation of Basic Education in the New Normal as Supported by Stakeholders in terms of the Learning Delivery Modality for Teachers (LDM2)

\begin{tabular}{|l|c|c|c|}
\hline \multicolumn{1}{|c|}{$\begin{array}{c}\text { Learning Delivery Modality for Teachers } \\
\text { (LDM2) }\end{array}$} & Mean & SD & Verbal Description \\
\hline Module 1- Course Orientation & 3.57 & .676 & Highly Implemented \\
\hline $\begin{array}{l}\text { Module 2- Most Essential Learning } \\
\text { Competencies (MELCs) }\end{array}$ & 3.57 & .672 & Highly Implemented \\
\hline $\begin{array}{l}\text { Module 3a- Lesson Design and } \\
\text { Assessment }\end{array}$ & 2.57 & .870 & Implemented \\
\hline Module 3b- Learning Resources & 3.57 & .672 & Highly Implemented \\
\hline $\begin{array}{l}\text { Module 4- Professional Development } \\
\text { and LAC Planning }\end{array}$ & 3.58 & .662 & Highly Implemented \\
\hline \multicolumn{1}{|c|}{ Overall } & 3.37 & 0.71 & Implemented \\
\hline
\end{tabular}

Legend: (4.51 - 5.00) Extremely Implemented/Supported (EI, ES); (3.51 - 4.50) Highly Implemented/Supported (HI, HS); 2.51 - 3.50 Implemented/Supported (I, S); (1.51 - 2.50) Moderately Implemented/Supported (MI, MS); (1.00 - 1.50) Not Implemented/Supported (NI,NS)

Tuscano (2020) stressed that teachers encourage pupils to learn, virtual learning activities such as online collaborative work must be initiated since module 3a or Lesson Design and Assessment of teachers has the least mean. Teachers should be more innovative, encourage students to participate actively in virtual or modular learning, and engage students in deeper learning in order to achieve the desired learning results, particularly the MELCs are met. Corollary to this, Saxena (2020) created a framework for teachers' role during the epidemic It emphasizes the instructional levels for effective learning, which allow immature learners' anxieties and mysteries to be revealed, especially in this challenging situation where the COVID-19 virus is still existing.

Table 14 illustrates the summary on the test of the significant relationship between systems and tools and stakeholder's support for the implementation of basic education in the new normal. It can be gleaned that there is a "significant relationship" between these variables at the .01 level. Most of the stakeholders' support indicates a high correlation with a substantial relationship between the variables indicated on the system and tools on the implementation of basic education in the new normal. 
International Journal of Theory and Application in Elementary and Secondary School Education (IJTAESE), Vol. 3 (2), 76-90 An Input for Stakeholders' Management and Engagement Primer (SMEP) of Basic Education in the New Normal in Laguna Cluster, Philippines Insight

Melanie C. Caňo, Consorcia S. Tan, EdD, Marcial M. Bandoy, EdD, Albert D. Yazon, EdD, Lerma P. Buenvinida, EdD

Table 14. Summary on the Test of Significant Relationship Between Systems and Tools and Stakeholders Support for the Implementation of Basic

\begin{tabular}{|c|c|c|c|c|c|c|c|}
\hline \multirow{2}{*}{$\begin{array}{l}\text { Systems and } \\
\text { Tools }\end{array}$} & \multicolumn{7}{|c|}{ Category of Stakeholder's Support } \\
\hline & $\begin{array}{l}\text { Learning } \\
\text { Env'ment }\end{array}$ & $\begin{array}{l}\text { Learning } \\
\text { Support }\end{array}$ & $\begin{array}{l}\text { Technology } \\
\text { Support }\end{array}$ & $\begin{array}{l}\text { Health \& } \\
\text { Nutrition }\end{array}$ & $\begin{array}{l}\text { Reading } \\
\text { Program }\end{array}$ & $\begin{array}{c}\text { Training \& } \\
\text { Dev't }\end{array}$ & $\begin{array}{c}\text { Direct } \\
\text { Assistance }\end{array}$ \\
\hline LDM & $.489^{* *}$ & $.584^{* *}$ & $.557^{* *}$ & $.531^{* *}$ & $.586 * *$ & $.595^{* *}$ & $.522^{* *}$ \\
\hline MELCS & $.576^{* *}$ & $.586 * *$ & $.590^{* *}$ & $.448^{* *}$ & $.462^{* *}$ & $.550 * *$ & $.544^{* *}$ \\
\hline PIVOTIVA & $.577^{* *}$ & $.596 * *$ & $.596 * *$ & $.435^{* *}$ & $.454^{* *}$ & $.550 * *$ & $.549^{* *}$ \\
\hline WHLP & $.597^{* *}$ & $.605^{* *}$ & $.613^{* *}$ & $.431^{* *}$ & $.455^{* *}$ & $.565^{* *}$ & $.542^{* *}$ \\
\hline LCP & $.681^{* *}$ & $.710^{* *}$ & .733 & $.554^{* *}$ & $.571 * *$ & $.676^{* *}$ & $.633^{* *}$ \\
\hline LDM $_{\text {teacher }}$ & $.304^{* *}$ & $.385^{* *}$ & $.391 * *$ & $.562^{* *}$ & $.568 * *$ & .460 & $.370^{* *}$ \\
\hline
\end{tabular}

${ }^{* *}$ significant at $\mathrm{p}<.01$

It is worthy to note that LDMs were found to have a "significant relationship" with all the indicators of stakeholders' support at a 01 level of significance. A moderate uphill (positive) relationship exists as manifested by .489 for learning environment, .584 for learning support, .557 for technology support, .531 for health and nutrition, .586 for reading program, .595 for training and development and .522 for direct assistance.

This means that the stakeholders' support needed by the learners in time of pandemic is extended in all learning delivery modalities. The finding is supported by the study of Ancheta (2020), who concluded that most countries throughout the world are concentrating on how to begin the new school year within the "new normal" of teaching and learning without robbing pupils of their entitlement to a good education.

Table 15 illustrates the test of prediction on the interactive effect of school size on the system of tools for the implementation of basic education in the new normal. In the first step, the number of predictors was controlled by considering only those that showed a greater correlation coefficient value. The training and development $(\mathrm{r}=.164)$ was entered into the first step of the regression analysis and showed significance where $F(1,684)=531.916, p<.01$. Likewise, the R-squared value of .451 explains that the training and development alone explains to such extent the variability of the level of implementation of basic education in the new normal.

Table 15. Test of Prediction on the Interactive Effect of School Size to the Systems and Tools for the Level of Implementation of Basic Education in the New Normal

\begin{tabular}{|c|c|c|c|c|c|c|}
\hline \multirow[t]{2}{*}{ Step } & \multirow[t]{2}{*}{ Predictors } & \multicolumn{2}{|c|}{$\begin{array}{l}\text { Unstandardized } \\
\text { Coefficients }\end{array}$} & \multirow{2}{*}{$\begin{array}{c}\begin{array}{c}\text { Standardized } \\
\text { Coefficients }\end{array} \\
\text { Beta } \\
\end{array}$} & \multirow[t]{2}{*}{ t-value } & \multirow[t]{2}{*}{ p-value } \\
\hline & & B & Std. Error & & & \\
\hline 1 & $\begin{array}{l}\text { Constant } \\
\text { Training \& } \\
\text { Development }\end{array}$ & $\begin{array}{c}1.622 \\
.547\end{array}$ & $\begin{array}{l}.070 \\
.024\end{array}$ & .671 & $\begin{array}{l}23.101 \\
23.063\end{array}$ & $\begin{array}{l}.000 \\
.000\end{array}$ \\
\hline 2 & $\begin{array}{l}\text { Constant } \\
\text { Training \& } \\
\text { Development } \\
\text { School Size }\end{array}$ & $\begin{array}{l}1.607 \\
.546 \\
.007\end{array}$ & $\begin{array}{l}.084 \\
.024 \\
.021\end{array}$ & $\begin{array}{l}.670 \\
.010\end{array}$ & $\begin{array}{c}19.120 \\
22.681 \\
.337\end{array}$ & $\begin{array}{l}.000 \\
.000 \\
.736\end{array}$ \\
\hline
\end{tabular}

$1 \mathrm{~F}(1,684)=531.916 ; \mathrm{p}<.01 ; \mathrm{R} 2=. .451$ Dependent Variable: Implemented System and Tools $2 \mathrm{~F}(2,647)=265.651 ; \mathrm{p}<.01 ; \mathrm{R} 2=.000$ of BE for the New Normal 
International Journal of Theory and Application in Elementary and Secondary School Education (IJTAESE), Vol. 3 (2), 76-90

An Input for Stakeholders' Management and Engagement Primer (SMEP) of Basic Education in the New Normal in Laguna Cluster, Philippines Insight

Melanie C. Caňo, Consorcia S. Tan, EdD, Marcial M. Bandoy, EdD, Albert D. Yazon, EdD, Lerma P. Buenvinida, EdD

In the second step of the analysis, the school size was included in the model to test whether such would moderate the effect of the training and development in the level of implementation of basic education in the new normal. Again, the model was significant at $\mathrm{F}(2,647), \mathrm{p}<.01$. In connection, the support of stakeholders for training and development in the implementation of basic education in the new normal shift in accordance to BE-LCP or DepEd Order no. 12, series of 2020 emphasized the strict compliance for standard health protocols while COVID 19 virus still exists in the environment.

However, no changes are observed in the R- squared value. In the first step, the Training \& Development (.547) is significant and indicates that each point increases in the provision of training and development for teachers, it heightened the level of the implementation of basic education by an average of approximately 54.70 percent while holding other predicting variable constant. However, in the second step, guided by the intent of knowing the moderating effect, no substantial interactive effect was observed in the regression coefficient since the 'school size' is not statistically significant.

Table 16 shows the test of a significant relationship between tools and systems for the implementation of basic education and school size.

Table 16. Test of Significant Relationship Between Tools and System for the Implementation of Basic Education and School Size

\begin{tabular}{|c|c|c|c|c|c|c|c|}
\hline & \multicolumn{7}{|c|}{ Category of Stakeholder's Support } \\
\hline & $\begin{array}{l}\text { Learning } \\
\text { Env'ment }\end{array}$ & $\begin{array}{l}\text { Learning } \\
\text { Support }\end{array}$ & $\begin{array}{l}\text { Technology } \\
\text { Support }\end{array}$ & $\begin{array}{l}\text { Health \& } \\
\text { Nutrition }\end{array}$ & $\begin{array}{l}\text { Reading } \\
\text { Program }\end{array}$ & $\begin{array}{c}\text { Training \& } \\
\text { Dev't }\end{array}$ & $\begin{array}{c}\text { Direct } \\
\text { Assistance }\end{array}$ \\
\hline School Size & $.150^{* *}$ & $.156^{* *}$ & $.158^{* *}$ & .013 & $.077^{*}$ & $.164^{* *}$ & $.141^{* *}$ \\
\hline
\end{tabular}

Stakeholders' support and school size have a high "significant relationship" in terms of Learning Environment $(\mathrm{r}=0.150)$, Learning Support $(\mathrm{r}=0.156)$, Technology Support $(\mathrm{r}=0.158)$, Training and Development ( $\mathrm{r}=0.164)$, and Direct Assistance $(\mathrm{r}=0.141)$ but found to be highly significant at 0.01 level. This means that for the school stakeholders, the size of the school influences the amount of support they could offer. Meanwhile, there is a low "significant relationship" between the school size and the support that stakeholders could give in Health and Nutrition ( $\mathrm{r}=0.013)$ and Reading Program $(\mathrm{r}=0.077)$. This connotes that the school size has something to do with these variables as to the level of support the stakeholders could give. Thus, school size is generally a determinant of stakeholders' level of support.

\section{CONCLUSION}

Stakeholders highly supported the implementation of basic education in the new normal in terms of Health and Nutrition Support. However, stakeholders' support for Learning Environment, Learning Support or Learning Assistive Devices, Technology Support, and Training and Development were moderately supported. While-Reading Programs and Direct Assistance were supported during the implementation of basic education in the new normal.

Learning Delivery Modality (LDM2) for Teachers, Most Essential Learning (MELCs), PIVOT 4-A CALABARZON Budget of Work (BOW), Weekly Home Learning Plan, and Learning Continuity Plan (LCP) were highly implemented for basic education in the new normal. Hence, Learning Delivery Modalities (LDMs) were at least implemented and supported by the stakeholders.

There is a significant relationship between the level of stakeholders' support and the level of implementation of basic education in the new normal. Most of the stakeholders' support indicates a high correlation with a substantial relationship between the variables indicated on the system and tools on the implementation of basic education in the new normal. 
International Journal of Theory and Application in Elementary and Secondary School Education (IJTAESE), Vol. 3 (2), 76-90

An Input for Stakeholders' Management and Engagement Primer (SMEP) of Basic Education in the New Normal in Laguna Cluster, Philippines Insight

Melanie C. Caňo, Consorcia S. Tan, EdD, Marcial M. Bandoy, EdD, Albert D. Yazon, EdD, Lerma P. Buenvinida, EdD

The prediction on the interactive effect of the school size to the systems and tools for the implementation of basic education in the new normal, Training \& Development is significant in the first step. However, in the second step, guided by the intent of knowing the moderating effect, no substantial interactive effect was observed in the regression coefficient since the 'school size' is not statistically significant.

Stakeholders' support and school size have a highly significant and positive relationship in terms of Learning Environment, Learning Support, Technology Support, Training and Development, and Direct Assistance. However, there is a low significant relationship between the school size and the stakeholders' support for Health and Nutrition and Reading Program. Hence, school size is generally a determinant of stakeholders' level of support.

SDOs and public elementary schools may adopt the Stakeholders' Management and Engagement Primer (SMEP) nor craft their own contextualized and modified. SMEP and use it as a intervention and guide in dealing with the stakeholders within and across their community. Intensive monitoring of the school's top management through Strength, Weaknesses, Opportunities, Threat analysis in the stakeholders' support even in the time of the global health pandemic.

Learning Leaders may encourage the stakeholders to participate in crafting and designing long and short-term plans and solicit stakeholders' feedback.

\section{REFERENCES}

Ancheta, RF. (2020). The New Normal in Education: A Challenge to the Private Basic Education Institutions in the Philippines, Volume 1, Issue 1 September 2020 • ISSN 2719-0633 (PRINT) 2719-0641 (ONLINE), from https://iiari.org/wp- content/uploads/2020/09/The-New-Normal-in- Education-1.pdf

Applying community capacity-building approaches to child welfare practice and policy.CFCA Paper No. 13. April 2013. Retrieved from https://aifs.gov.au/cfca/publications/applying-community-capacitybuilding- approaches-child- wel/understanding-community

Bartolome M., Mamat N., and Masnan AH. (2017). Parental Involvement in the Philippines: A Review of Literatures, International Journal of Early Childhood Care, Volume 6, 2017- ISSN 2289-3156/ Eissn 23501763(41-50) (ONLINE), from https://eric.ed.gov/

Brammer S., and Clark T. (2020). PMC7361877COVID-19 and Management Education: Reflections on Challenges, Opportunities, and Potential Futures, from https://www.ncbi.nlm.nih.gov/pmc/articles/PM C7361877/ Commission on Higher Education Research Agenda- 2 (2009-2018). Pg 1-11. https://ched.gov.ph/

Cuaton, GP. (2020). Philippines Higher Education Institutions in the time of COVID-19 Pandemic Philippines Higher Education Institutions in the time of COVID-19 Pandemic, from https://www.ceeol.com/search/article- detail?id=859377

Figlio D. and Kenny L. (2009). Public Sector Performance Measurement and Stakeholder Support pages 1069-1077

Francisco, C. (2020). The Emergence of Situational Leadership during COVID-19 Pandemic called New Normal Leadership, International Journal of Academic Multidisciplinary Research (IJAMR) ISSN: 2643-9670 Vol. 4 Issue 10, October - 2020, Pages: 15-19, from, https://hcommons.org/deposits/item/hc:33223/h ttps://en.unesco.org/covid19

Go-monilla, P. (2015). The Learning Environment and Its Effect on the Academic Performance of College Students, from https://ejournals.ph/article.php/

Gomez, N. (2020). Reflections on the role of occupational therapy programs on the mental health of stakeholders' transition to e-learning during the COVID-19 pandemic, from https://www.tandfonline.com/doi/full/10.1080/1 4473828.2020.1836791 
International Journal of Theory and Application in Elementary and Secondary School Education (IJTAESE), Vol. 3 (2), 76-90 An Input for Stakeholders' Management and Engagement Primer (SMEP) of Basic Education in the New Normal in Laguna Cluster, Philippines Insight

Melanie C. Caňo, Consorcia S. Tan, EdD, Marcial M. Bandoy, EdD, Albert D. Yazon, EdD, Lerma P. Buenvinida, EdD

Journal of Interprofessional Care Volume 34 (2020). Interprofessional education and collaborative practice research during the COVID-19 pandemic: Considerations to advance the field Pages 583-586 from, https://www.ncbi.nlm.nih.gov/pmc/articles/PM C7361877/

Kuswardhani, RM. (2020). Leadership Practices Amidst the Global Pandemic - A Case Study Exploring Distributed Leadership in an International School In South East Asia, from https://search.proquest.com/openview/a37f8fb7663c9f1256e0bf6fed715435/1?pqorigsite=gscholar\&cbl $=18750 \&$ diss $=y$

Liego, M.A. Basic Education Reform Agenda. Retrieved October 24, 2020. https://www.teacherph.com/besra/

Luistro, A. Adoption of Basic Education reform Agenda. Retrived December 15, 2010. https://www.deped.gov.ph/2010/12/15/do-118-s-2010-adoption-of-the- new-besra- implementationarrangement-amended-by/

Miller R. and Lopez K., (2019). The Inclusion of Parental Stakeholders in the Development of an Interactive Parenting Education Tool from, https://doi.org/10.1007/s10578-018-0852-2.

Riley, J. (2016). Lewins Model of Force Field Analysis, from https://www.tutor2u.net/business/reference/mode ls-of-change-management- Lewin's-force-field- model

Roberts N., and Bradley RT (2008). Stakeholder Collaboration and Innovation: A Study of Public Policy Initiation at the State Level First Published June 1, 1991 retrieved from, https://onlinelibrary.wiley.com/doi/abs/10.1111/j.1541-0072.2008.00275.x

Sam, S. (2020). Psychological and Operational Challenges in Educational Field amidst Pandemic from https://lumenpublishing.com/journals/index.php/rrem/article/view/2794

Smith, A., Thomas E., and Snoswell. (2019). Telehealth for global emergencies: Implications for coronavirus disease 2019 (COVID-19), from https://www.ceeol.com/search/article- detail?id=859377 Author Name (s), Title of the Paper/Article, Proceedings of < Name of the conference>, Date \& Year, Place \& Country, Volume No., ISBN No. (if any), pp. (Printed Pages i.e. pp. 45-51)

Subong, P.E. Jr., and Beldia M.D. (2005). Statistics for Research: First Edition 2005: Rex Book Store Inc.

Tabuga, et al., (2020). Innovating Governance: Building Resilience against COVID-19 Pandemic and Other Risks September 2020， from https://thinkasia.org/handle/11540/12519 